\title{
On several new species of the millipede family Glomeridae from Vietnam (Diplopoda: Glomerida)
}

\section{О нескольких новых видов диплопод семейства Glomeridae из Вьетнама (Diplopoda: Glomerida)}

\author{
S.I. Golovatch ${ }^{1}$, J.-J. Geoffroy ${ }^{2} \&$ D. VandenSpiegel ${ }^{3}$ \\ С.И. Головач ${ }^{1}$ ЖК.-ЖК. ЖКоффруа², А. ВанденШпигемь ${ }^{3}$
}

\footnotetext{
${ }^{1}$ Институт проблем экологии и эволюции РАН, Ленинский пр. 33, Москва 119071 Россия.

${ }^{1}$ Institute for Problems of Ecology and Evolution, Russian Academy of Sciences, Leninsky pr. 33, Moscow 119071, Russia.

${ }^{2}$ Muséum national d'Histoire naturelle, Département Ecologie \& Gestion de la Biodiversité, UMR 7204 CESCO, 4, avenue du Petit Château, F-91800 Brunoy, France.

${ }^{2}$ Национальный музей естественной истории, Брюнуа, Франция.

${ }^{3}$ Musée Royal de l’Afrique centrale, B-3080 Tervuren, Belgium.

${ }^{3}$ Королевский музей Центральной Африки, Тервурен, Бельгия.
}

KEY WORDS: Diplopoda, Hyleoglomeris, Hyperglomeris, new species, Vietnam.

КЛЮЧЕВЫЕ СЛОВА: Diplopoda, Hyleoglomeris, Hyperglomeris, новый вид, Вьетнам.

ABSTRACT. Glomeridae in the fauna of Vietnam appear to show a remarkably high rate of endemism (100 and $60 \%$ at the species and generic levels, respectively) and currently encompass 17 unquestioned species in five genera, including Hyleoglomeris cavernicola sp.n., H. spelaea sp.n., H. colorata sp.n. and Hyperglomeris depigmentata sp.n.

РЕЗЮМЕ. У семейства Glomeridae в фауне Вьетнама примечательно высока степень эндемизма (coответственно 100 и $60 \%$ на видовом и родовом уровнях), и оно сейчас представлено там 17 неоспоримыми видами из пяти родов, включая Hyleoglomeris cavernicola sp.n., H. spelaea sp.n., H. colorata sp.n. и Hyperglomeris depigmentata sp.n.

\section{Introduction}

The millipede order Glomerida is long known to show one of the main centres of generic and species diversification in the Oriental realm [Golovatch et al., 2010]. The Oriental fauna of Glomerida is strongly dominated by the genus Hyleoglomeris Verhoeff, 1910, one of the largest and certainly the most widespread in the entire order Glomerida. At the moment, this basically warm temperate to tropical Eurasian genus contains 91 nominate species ranging from the Balkans in the West to Japan in the East, and the Sunda Archipelago (Sulawesi) in the Southeast [Golovatch et al., 2006, 2012].

Vietnam is known to support the following unquestioned glomeridan species and genera, arranged in alphabetic order [Enghoff et al., 2004; Golovatch et al., 2006]:
1. Annameris curvimana Verhoeff, 1915, described from an unspecified locality in central Vietnam (Annam) [Verhoeff, 1915].

2. Annameris robusta Verhoeff, 1921, described from an unspecified locality in northern Vietnam (Tonkin) [Verhoeff, 1921].

3. Hyleoglomeris robusta Attems, 1938, described from Peak Lang Bian near Dalat, southern Vietnam [Attems, 1938], redescribed from strictly topotypic material [Golovatch et al., 2006] and suggested as possibly a senior synonym of further two congeners known from the same or a nearby locality: $H$. maior Attems, 1938 and H. electa Silvestri, 1917, the latter taxon in the sense of Attems [1938].

4. Hyleoglomeris speophila Golovatch, Geoffroy et Mauriès, 2006, described from a cave on Cat Ba Island near Hai Phong, northern Vietnam [Golovatch et al., 2006].

5. Hyleoglomeris triangulifera Attems, 1938, known only from female material taken at Nhatrang, Khanh Hoa Prov., southern Vietnam [Attems, 1938].

6. Hyperglomeris conspicua Golovatch, 1983, described from Hoa Binh Prov., northern Vietnam [Golovatch, 1983].

7. Hyperglomeris dirupta (Silvestri, 1917), described from Lang Son Prov., northern Vietnam [Silvestri, 1917; Golovatch, 1983].

8. Hyperglomeris lamellosa Silvestri, 1917, described from Lang Son Prov., northern Vietnam [Silvestri, 1917; Golovatch, 1983].

9. Hyperglomeris maxima Golovatch, 1983, described from Hoa Binh Prov., northern Vietnam [Golovatch, 1983].

10. Peplomeris demangei Silvestri, 1917, described from Hanoi City, northern Vietnam [Silvestri, 1917]. 
11. Peplomeris magna Golovatch, 1983, described from Ninh Binh Prov., northern Vietnam [Golovatch, 1983], later recorded from the same locality [Korsós \& Golovatch, 1989].

12. Rhopalomeris tonkinensis Silvestri, 1917, described from Lang Son Prov., northern Vietnam [Silvestri, 1917].

In addition, one more, closer unidentified species of the genus Hyleoglomeris Verhoeff, 1910 has been recorded from the Cat Tien National Park, Dongnai Province, southern Vietnam [Golovatch et al., 2011].

The rate of endemism of Glomerida in Vietnam is notable, not only reaching $100 \%$ at the species level, but also being remarkably high $(60 \%)$ at the generic one. Thus, Annameris Verhoeff, 1915, Hyperglomeris Silvestri, 1917 and Peplomeris Silvestri, 1917 are endemic to Vietnam. This situation strongly contrasts with the known rates of glomeridan diversity in larger adjacent countries such as Thailand or China: some four species of Hyleoglomeris and one species of Rhopalomeris Verhoeff, 1906 yet reported from Thailand [Enghoff, 2005], and 23 species of Hyleoglomeris alone in continental China [Golovatch et al., 2012], plus another five Hyleoglomeris spp. and the monobasic genus Mauriesia Golovatch, Mikhaljova et Chang, 2010 from Taiwan [Golovatch et al., 2010].

The present paper puts on record another few new species of the family Glomeridae from Vietnam, based on the collection of the Muséum national d'Histoire naturelle, Paris, France (MNHN). All type material has been housed in MNHN, with the exception of one paratype which will be deposited in the Zoological Museum, State University of Moscow, Russia (ZMUM), as indicated below.

\section{Taxonomic part}

\section{Hyleoglomeris cavernicola sp.n.} Figs $1 \mathrm{~A}-\mathrm{C}$.

HOLOTYPE $O^{7}$ (MNHN CC 182), Vietnam, Hai Phong, Cat Ba Island, Viet Hai field, cave between village and springs, 15.06.2003, leg. P. Trontelj \& B. Sket.

PARATYPE + (MNHN CC 182), same locality, together with holotype.

NAME. To emphasize cavernicoly, a noun in apposition.

DIAGNOSIS. Differs from congeners in a rather large and completely unpigmented body, coupled with a rather long antennomere 6 which is ca 2.0-2.1 times as long as high, as well as by two transverse striae on the collum, a very narrow hyposchism which reaches or even faintly surpasses the caudal tergal margin of tergum 2, and ten transverse striae of which six cross the dorsum on tergum 2. Differs from the geographically closest and morphologically the most similar $H$. speophila Golovatch, Geoffroy et Mauriès, 2006, also from a cave on Cat Ba Island [Golovatch et al., 2006], mainly by the broadly subtrapeziform, slightly concave central lobe and simple, unarmed tips of the lateral horns of the telopod syncoxite (Fig. 1C).
DESCRIPTION. Length of holotype ca $10 \mathrm{~mm}$, width (maximum on tergum 2) ca $4.6 \mathrm{~mm}$; length of paratype ca $9.0 \mathrm{~mm}$, width on tergum $2 \mathrm{ca} 4.0 \mathrm{~mm}$. Body entirely pallid.

Ocelli ca $5+1$, convex, completely unpigmented, barely discernible; Tömösváry's organ transverse-oval, ca 1.6 times wider than long. Antennomere 6 rather long, ca 2.0-2.1 times as long as high.

Collum with two transverse striae. Tergum 2 (= thoracic shield) with a very narrow hyposchism extending behind to reach or even slightly surpass the caudal tergal margin; ten superficial transverse striae, only one starting below schism, 1 or 2 level to, all others above schism, while six (never last one from below) crossing the dorsum. $\sigma^{7}$ anal shield regularly rounded at caudal margin.

$\sigma^{7}$ leg 17 (Fig. 1A) with a high and irregularly shaped outer coxal lobe; telopodite 4-segmented.

$\sigma^{7}$ leg 18 (Fig. 1B) with an arch-shaped syncoxital notch; telopodite 4-segmented.

Telopods (Fig. 1C) with a rather low, subtrapeziform, slightly concave and sparsely setose central syncoxital lobe flanked by two setose horns, each latter crowned by a minute, elongate lobule devoid of adjacent structures. Prefemur and, to a far lesser extent and only parabasally, femur micropapillate laterally. Caudomedial femoral process prominent, directed distomedially at ca $100^{\circ}$ to femur, mostly strongly chitinized, apically with a small membranous sac, but devoid of any chitinized lobe. Caudomedial process of tibia evident, sac-shaped, membranous, with an evident, slightly micropapillate tubercle at base. Tarsus rather strongly sigmoid, subacuminate apically.

REMARKS. Due to certain troglomorphic features like the completely unpigmented body and ocelli, as well as the transversely clearly elongate Tömösváry's organ, this species seems to be a troglobite. The same obviously concerns $H$. speophila, a sympatric cavernicole [Golovatch et al., 2006].

\section{Hyleoglomeris spelaea $\mathbf{s p . n .}$} Figs 2A-C.

HOLOTYPE O (MNHN CC 183), Vietnam, Quang Binh Prov., Phong Nha, Cave Hang Nui Doi, ca $70 \mathrm{~m}$ a.s.1., $106.313346^{\circ} \mathrm{E}$, $17.583489^{\circ} \mathrm{N}$, hand collection, 25.11.2011, leg. L. Deharveng \& A. Bedos (Vn11-56).

NAME. To again emphasize cavernicoly.

DIAGNOSIS. Due to its troglomorphic traits, this new species seems to be particularly similar both to $H$. cavernicola sp.n. and $H$. speophila, but differs in being considerably smaller (ca 6.0 versus $8.5-10.0 \mathrm{~mm}$ long), showing fewer striae on tergum 2 , and a subquadrate central lobe of the telopod syncoxite (Fig. 2C).

DESCRIPTION. Length ca $6.0 \mathrm{~mm}$, width (maximum on tergum 2) ca $3.0 \mathrm{~mm}$. Body entirely unpigmented.

Ocelli about 4+1, convex, barely discernible; Tömösváry's organ transverse-oval, ca 1.6 times wider than long. Antennomere 6 ca 2.0 times as long as high. 


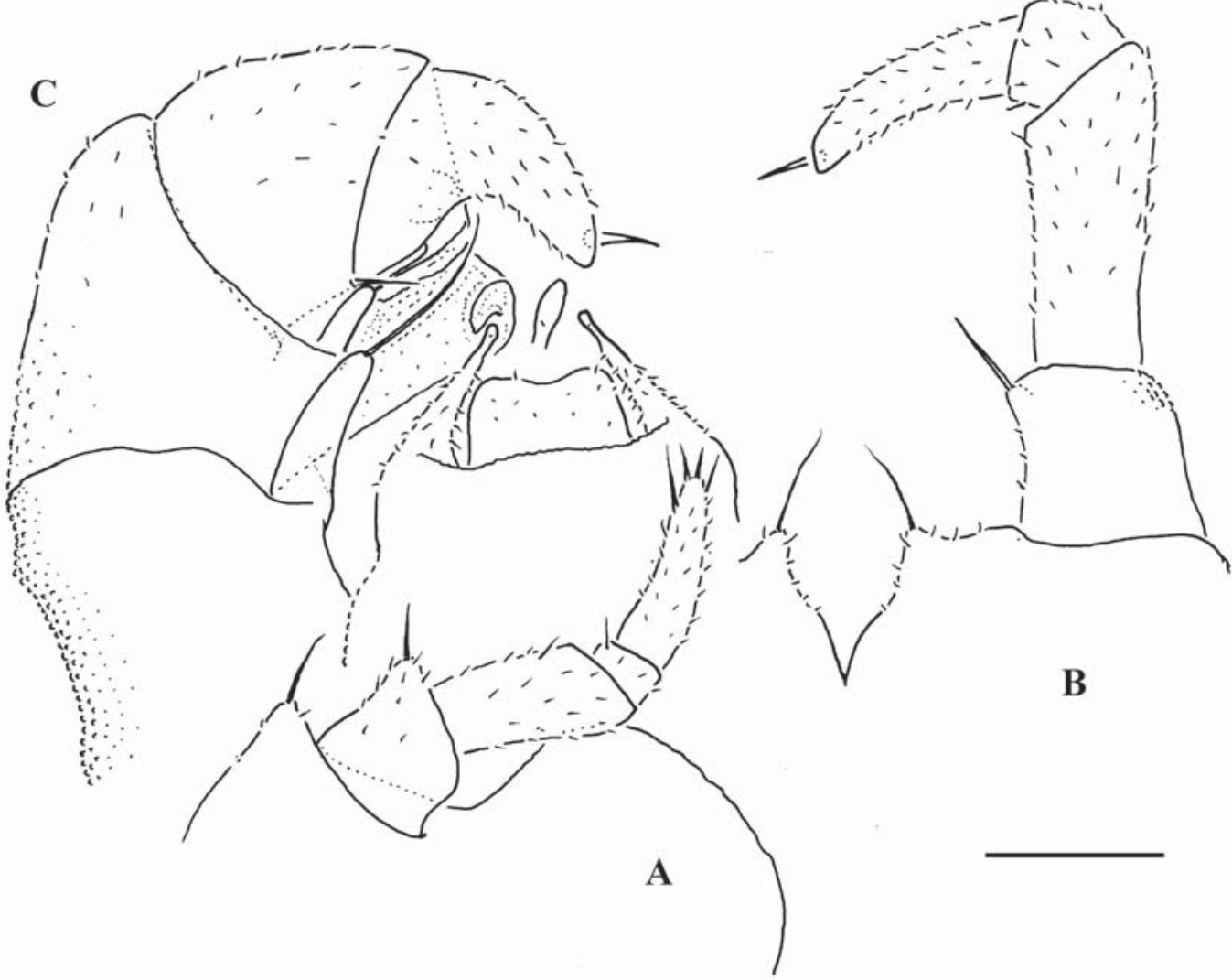

Fig. 1. Hyleoglomeris cavernicola sp.n., holotype: A - leg 17; B — leg 18; C - telopods, front view. Scale bar: $0.2 \mathrm{~mm}$. Рис. 1. Hyleoglomeris cavernicola sp.n., голотип: А - нога 17; В — нога 18; С - телоподы, спереди. Масштаб 0,2 мм.

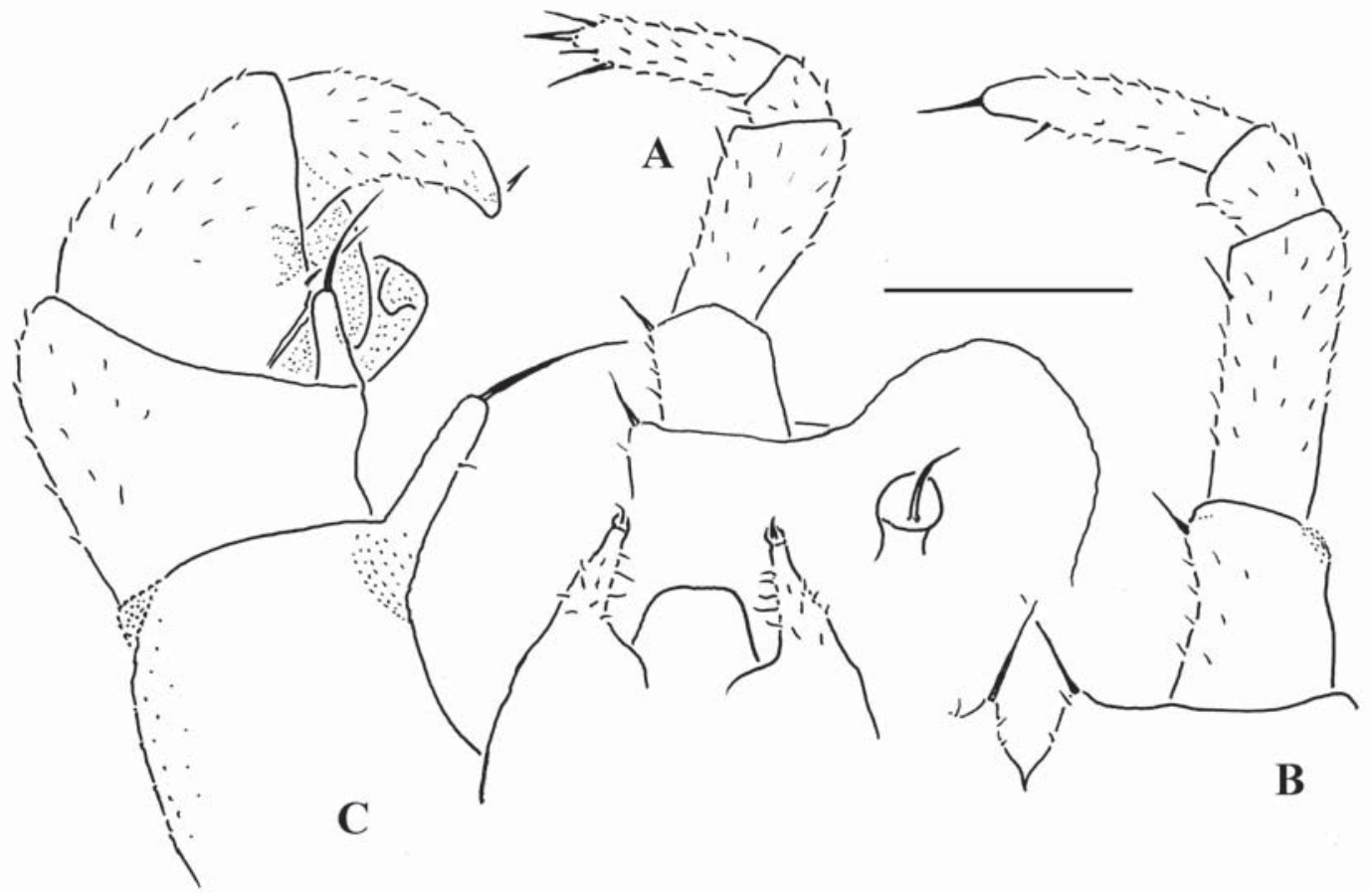

Fig. 2. Hyleoglomeris spelaea sp.n., holotype: A — leg 17; B — leg 18; C — telopods, front view. Scale bar: $0.2 \mathrm{~mm}$. Рис. 2. Hyleoglomeris spelaea sp.n., голотип: А - нога 17; В — нога 18; C - телоподы, спереди. Масштаб 0,2 мм. 

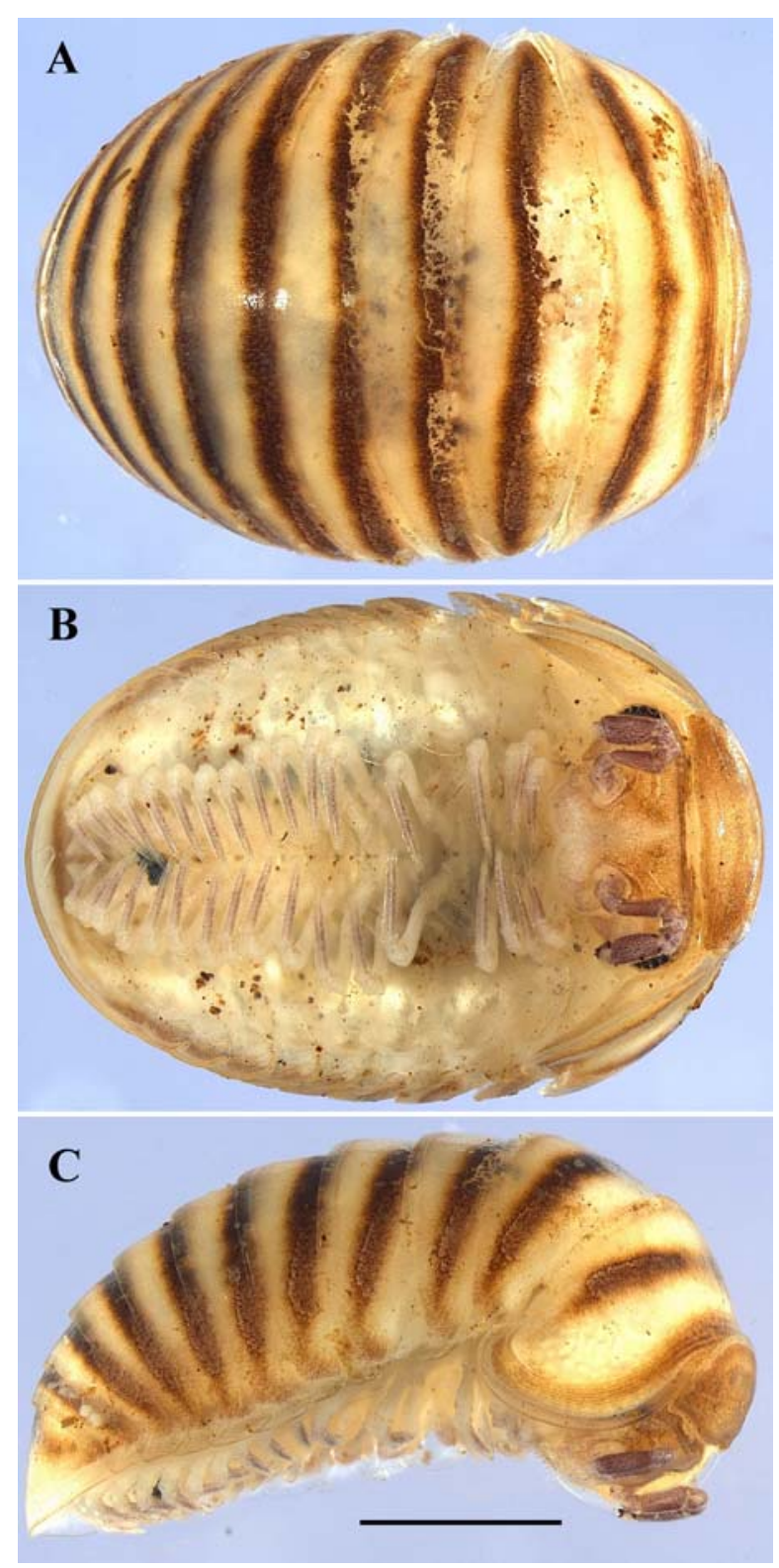

Fig. 3. Habitus of Hyleoglomeris colorata sp.n., paratype: A$\mathrm{C}$ - dorsal, ventral and lateral views, respectively. Scale bar: 1.0 $\mathrm{mm}$.

Рис. 3. Внешний вид Hyleoglomeris colorata sp.n., паратип: А-C - соответственно сверху, снизу и сбоку. Масштаб 1,0 мм.

Collum with two transverse striae. Tergum 2 with a very narrow hyposchism extending behind to reach the caudal tergal margin; six superficial transverse striae, one starting below, one level to, the remaining four above schism, of which only three (not last one) crossing the dorsum. Anal shield regularly rounded at caudal margin.

Leg 17 (Fig. 2A) with a moderately high and irregularly shaped outer coxal lobe; telopodite 4-segmented.

Leg 18 (Fig. 2B) with a nearly V-shaped syncoxital notch; telopodite 4-segmented.

Telopods (Fig. 2C) with a rather high, subquadrate, bare, central syncoxital lobe flanked by two setose horns, each latter crowned by a minute, elongate lobule with a flagelloid filament. Prefemur micropapillate laterally. Caudomedial femoral process prominent, crowned by a membranous sac, but devoid of any chitinized lobe. Caudomedial process of tibia very evident, membranous; tibial tubercle on caudal face low and micropapillate. Tarsus rather clearly sigmoid, subacuminate apically.

REMARKS. Due to several troglomorphic features like the completely unpigmented body and ocelli, this new species also seems to represent a troglobite.

\section{Hyleoglomeris colorata $\mathbf{s p . n .}$}

Figs 3, 4.

HOLOTYPE O' (MNHN CC 184), Vietnam, Quang Binh Prov., Phong Nha, near Cave Dong Thien Duong, ca $130 \mathrm{~m}$ a.s.1., $106.228123^{\circ} \mathrm{E}, 17.530789^{\circ} \mathrm{N}$, litter, Berlese extraction, 19.11.2011, leg. L. Deharveng \& A. Bedos (Vn11-28).

PARATYPE + (MNHN CC 184), same locality, together with holotype.

NAME. To emphasize the clear-cut colour pattern.

DIAGNOSIS. Differs from congeners by the peculiar, annulated colour pattern (Fig. 3), coupled with a 3-segmented $\sigma^{7}$ telopodite 17 (Fig. 4A).

DESCRIPTION. Length of holotype ca $5.0 \mathrm{~mm}$, width (maximum on tergum 2) ca $2.2 \mathrm{~mm}$. Length of paratype ca $6.0 \mathrm{~mm}$, width on tergum 2 ca $2.7 \mathrm{~mm}$. Body pigmented, pattern annulated (Fig. 3): background dirty whitish to yellowish with rather narrow, regular, contrasting brown bands across $3^{\text {rd }}$ quarter of extent of terga $2-11$, only tergum 2 also with a similarly narrow, slightly paler band along front margin; pygidium with a transverse band only in front quarter. Head and collum more regularly coloured, marbled brown, only central and sometimes also caudal parts of collum a little lighter, brown-yellowish. Venter flavous. Antennae rusty brown, distal podomeres very faintly rusty brown. Ocelli blackish.

Ocelli $6+1$, convex, distinct; Tömösváry's organ transverse-oval, ca 1.3-1.4 times wider than long. Antennomere 6 ca 1.7 times as long as high.

Collum with two transverse striae. Tergum 2 with a rather broad hyposchism extending behind to reach the caudal tergal margin; eight superficial transverse striae, five starting below, one level to, the remaining two above schism, of which only four (not last two ones) crossing the dorsum. Anal shield regularly rounded at caudal margin.

$\sigma^{7}$ leg 17 (Fig. 4A) with a moderately high and irregularly shaped outer coxal lobe; telopodite 3-segmented.

$\sigma^{7}$ leg 18 (Fig. 4B) with a nearly V-shaped syncoxital notch; telopodite 4-segmented.

Telopods (Fig. 4C) with a rather high, roundly subtrapeziform, bare, central syncoxital lobe flanked by two setose horns, each latter crowned by a minute, elongate lobule devoid of adjacent structures. Prefemur micropapillate laterally. Caudomedial femoral process prominent, micropapillate distally, crowned by a membranous sac, but devoid of any chitinized lobe. 


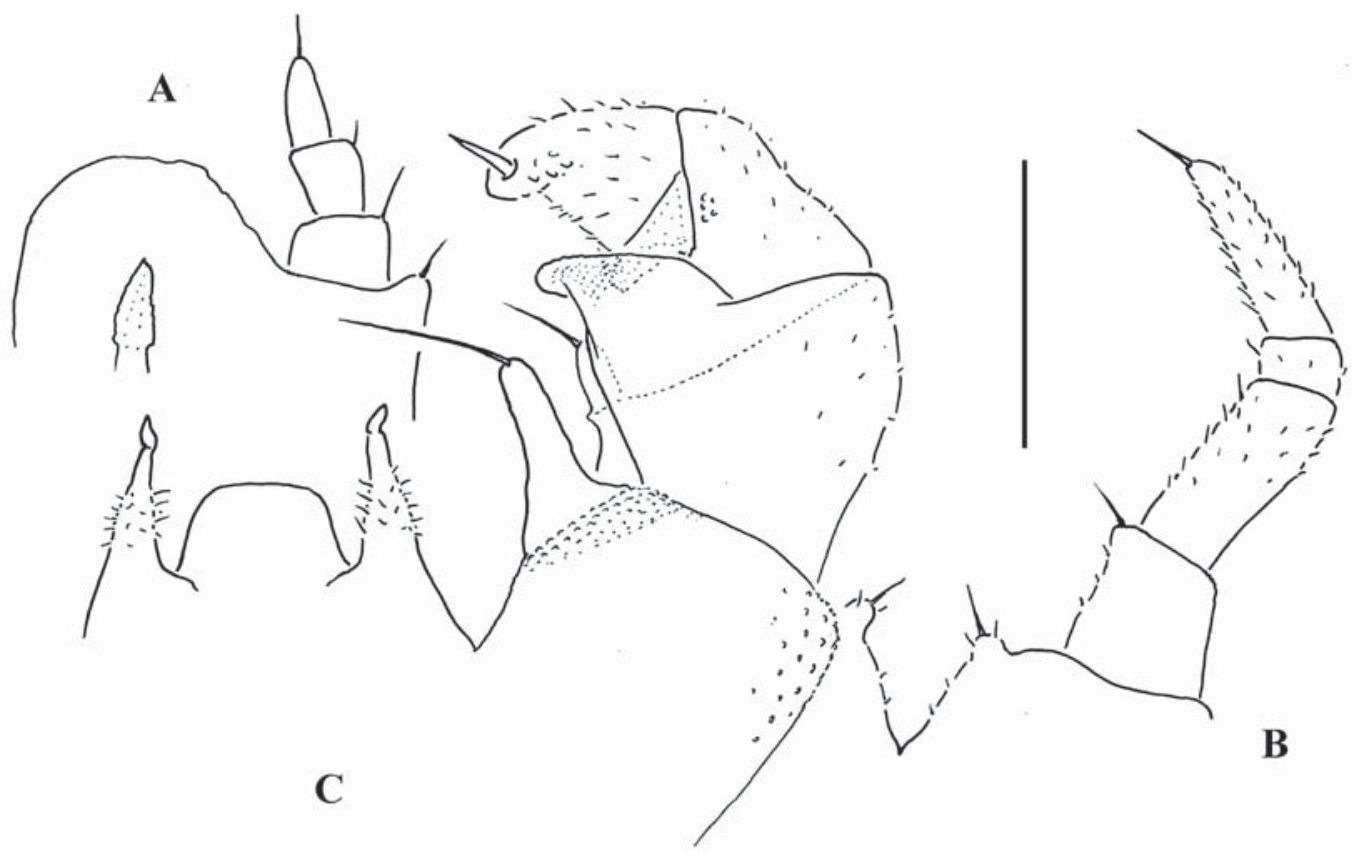

Fig. 4. Hyleoglomeris colorata sp.n., holotype: A — leg 17; B - leg 18; C — telopods, caudal view. Scale bar: $0.2 \mathrm{~mm}$. Рис. 4. Hyleoglomeris colorata sp.n., голотип: А - нога 17; В - нога 18; С - телоподы, сзади. Масштаб 0,2 мм.

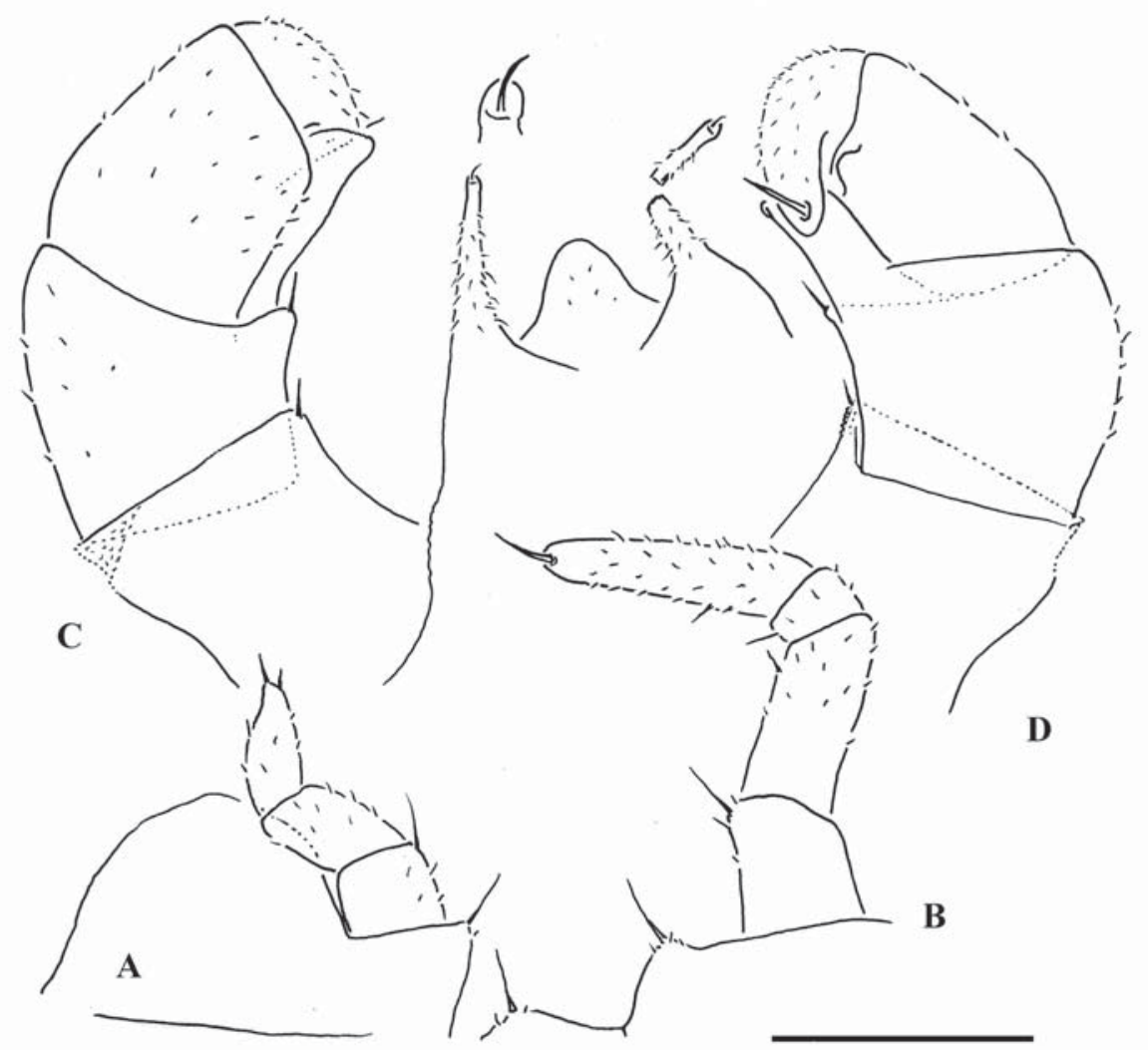

Fig. 5. Hyperglomeris depigmentata sp.n., $\mathrm{O}^{7}$ paratype: A $-\operatorname{leg} 17$; B $-\operatorname{leg} 18 ; \mathrm{C}, \mathrm{D}-$ telopods, front and caudal views, respectively. Scale bar: $0.2 \mathrm{~mm}$.

Рис. 5. Hyperglomeris depigmentata sp.n., паратип О': А — нога 17; В - нога 18; С, D - телоподы, соответственно спереди и сзади. Масштаб 0,2 мм. 
Caudomedial process of tibia evident, membranous; tibial tubercle on caudal face very low and micropapillate. Tarsus stout, clearly sigmoid, narrowly rounded at tip and papillate subapically.

\section{Hyperglomeris depigmentata sp.n.} Fig. 5.

HOLOTYPE Ơ (MNHN CC 185), Vietnam, Thanh Hoa Prov., Than Son, Lang Kho Muong, Cave Hang Doi, $105.137465^{\circ} \mathrm{E}$, $20.496176^{\circ} \mathrm{N}$, hand collection, 13.12.2003, leg. L. Deharveng \& A. Bedos (Vn0312-27).

PARATYPES: $1 \bigcirc^{7}, 2$ 우 (MNHN CC 185), $1 \sigma^{7}$ (ZMUM), same locality, together with holotype. body.

NAME. To emphasize the completely unpigmented

DIAGNOSIS. Differs from congeners by the completely unpigmented body (troglomorphy), coupled with a 3-segmented $O^{7}$ telopodite 17 (Fig. 5A).

DESCRIPTION. Length of holotype ca $6.0 \mathrm{~mm}$, width (maximum on tergum 2) ca $3.0 \mathrm{~mm}$. Length of paratypes ca $5.5\left(\sigma^{7}\right)$ to $7.0 \mathrm{~mm}(+)$, width on tergum 2 ca $2.2\left(\sigma^{7}\right)$ to $3.0 \mathrm{~mm}(+)$. Body entirely unpigmented.

Ocelli ca $4+1$ or $5+1$, convex, indistinct; Tömösváry's organ transverse-oval, ca 1.2-1.3 times wider than long. Antennomere 6 ca 1.7 times as long as high.

Collum with two transverse striae. Tergum 2 with a rather broad hyposchism slightly extending behind caudal tergal margin; 8-9 superficial transverse striae, four starting below, 1-2 level to, the remaining three, all faintly impressed, above schism, of which only 4-5 (not last two ones) crossing the dorsum. Anal shield regularly rounded at caudal margin.

$\mathrm{O}^{7}$ leg 17 (Fig. 5A) with a high and slightly irregularly shaped outer coxal lobe; telopodite 3-segmented.

$\sigma^{7}$ leg 18 (Fig. 5B) with a broad, subtriangular syncoxital notch; telopodite 4-segmented.

Telopods (Figs 5C, D) with a rather high, roundly subtriangular, very poorly setose, central syncoxital lobe flanked by two setose horns, each latter crowned by a minute, elongate lobule with a setoid filament. Prefemur micropapillate distolaterally. Femoral and tibial trichosteles rudimentary, each represented by a strong seta alone. Caudomedial femoral process prominent, devoid of an apical membranous sac. No caudomedial process of tibia; tibial tubercle on caudal face very low and glabrous. Tarsus quite stout, clearly sigmoid, rather narrowly rounded at tip.

REMARKS. This is the first troglomorphic, likely also troglobitic, congener to be found. All four previously known species of the genus have been keyed [Golovatch, 1983].
ACKNOWLEDGEMENTS. We are obliged to all relevant collectors involved: Peter Trontelj and Boris Sket (both University of Ljubljana, Slovenia), and Louis Deharveng and Anne Bedos (both MNHN, Paris, France). Part of the material was collected during the cave biodiversity assessment of $\mathrm{Pu}$ Luong Nature Reserve, sponsored by Fauna Flora International Vietnam. Another part of the material was taken during a biodiversity survey of cave invertebrates in the framework of the Nature Conservation and Sustainable Natural Resource Management in Phong Nha - Ke Bang National Park Region Project, with the support of the German Development Cooperation in Vietnam. Special thanks go to the MNHN administration for financing the first author's stay in Paris in March and April 2013.

\section{References}

Attems C. 1938. Die von Dr C. Dawydoff in Französisch Indochina gesammelten Myriopoden // Mémoires du Muséum national d'Histoire naturelle, n.s. T.6. Fasc.2. P.187-353.

Enghoff H. 2005. The millipedes of Thailand (Diplopoda) // Steenstrupia. Vol.29. No.1. P.87-103.

Enghoff H., Golovatch S.I., Nguyen Duc A. 2004. A review of the millipede fauna of Vietnam (Diplopoda) // Arthropoda Selecta. Vol.13. Nos 1-2. P.29-43.

Golovatch S. I. 1983. On several new Glomeridae (Diplopoda) from Indochina // Annales Historico-Naturales Musei Nationalis Hungarici. T.75. P.107-116.

Golovatch S.I., Geoffroy J.-J., Mauriès J.-P. 2006. Review of the millipede genus Hyleoglomeris Verhoeff, 1910 (Diplopoda, Glomerida, Glomeridae), with descriptions of new species from caves in Southeast Asia // Zoosystema. Vol.28. No.4. P.887-915.

Golovatch S.I., Liu W.X., Geoffroy J.-J. 2012. Review of the millipede genus Hyleoglomeris Verhoeff, 1910 in China, with descriptions of new species (Diplopoda, Glomerida, Glomeridae) // Zootaxa. No.3358. P.1-27.

Golovatch S.I., Mikhaljova E.V., Chang H.W. 2010. Pill-millipedes (Glomerida, Diplopoda) in Taiwan // Zootaxa. No.2477. P.1-20.

Golovatch S.I., Tiunov A.V., Anichkin A.E. 2011. [Millipedes (Diplopoda)] // Tiunov A.V. (ed.). Struktura i funktsii pochvennogo naseleniya tropicheskogo mussonnogo lesa (natsionalnyi park Cat Tien, Yuzhnyi Vietnam). Moscow: KMK Sci. Press. P.76-90 [in Russian, English summary].

Korsós Z., Golovatch S.I. 1989. Addenda to the millipede fauna of Vietnam (Diplopoda) // Acta Zoologica Hungarica. T.35. Fasc.3/4. P.211-220

Silvestri F. 1917. Contributions to a knowledge of the Oriental Diplopoda Oniscomorpha. 1. The family Glomeridae // Records of the Indian Museum. Vol.13. P.103-151.

Verhoeff K.W. 1915. Zur Kenntnis der Plesiocerata. (Über Diplopoden, 82. Aufsatz) // Zoologischer Anzeiger. Bd.46. H.1. S.16-48.

Verhoeff K.W. 1921. Chilognathen-Studien. (91. Diplopoden-Aufsatz) // Archiv für Naturgeschichte. Bd.86A. H.12. S.23-80 (for 1920).

Responsible editor K.G. Mikhailov 